AperTO - Archivio Istituzionale Open Access dell'Università di Torino

\title{
A XANES study of chromophores in archaeological glass
}

\section{This is the author's manuscript}

Original Citation:

\section{Availability:}

This version is available http://hdl.handle.net/2318/118862

since 2016-06-07T11:31:39Z

Terms of use:

Open Access

Anyone can freely access the full text of works made available as "Open Access". Works made available under a Creative Commons license can be used according to the terms and conditions of said license. Use of all other works requires consent of the right holder (author or publisher) if not exempted from copyright protection by the applicable law. 


\title{
Applied Physics A \\ A XANES study of chromophores in archaeological glass --Manuscript Draft--
}

Manuscript Number:

Full Title:

Article Type:

Corresponding Author:
APYA-D-12-00685R1

A XANES study of chromophores in archaeological glass

SI: SR2A

Rossella Arletti

Università di Torino

Torino, ITALY

\section{Corresponding Author Secondary} Information:

Corresponding Author's Institution:

Università di Torino

Corresponding Author's Secondary Institution:

First Author:

Rossella Arletti

First Author Secondary Information:

Order of Authors:

\author{
Rossella Arletti \\ Simona Quartieri, Prof. \\ Ian C. Freestone, Prof.
}

Order of Authors Secondary Information:
Abstract:
We applied X-ray Absorption Near Edge Spectroscopy (XANES) to obtain information on the origin of glass color of several archaeological samples and on the oxidation conditions employed during their production. We studied a series of selected glass fragments mainly from excavated primary and secondary production centers and dated to the first millennium AD containing iron and manganese in a wide compositional range. In most of the studied samples iron is rather oxidized, while Mn $\mathrm{K}$-edge XANES data show that, in all the studied glass, Mn is mainly present in its reduced form (predominantly $2+$ ), with the possible subordinate presence of Mn3+. The most oxidized samples are the HIMT (High Iron Manganese Titanium) glasses, while the less oxidized belong to the primary natron glass series from the early Islamic tank furnaces at Bet Eliezer (Israel), and to the series coming from a Roman glass workshop excavated in Basinghall Street, London. In these glasses, iron is approximately equally distributed over the $2+$ and $3+$ oxidation states. The XANES analyses of two glass which had been deliberately decolorized using $\mathrm{Sb}$ - and $\mathrm{Mn}$ - based decolorizers, demonstrate that $\mathrm{Sb}$ is more effective than $\mathrm{Mn}$ as oxidant.

\section{Response to Reviewers:}
Torino 04/10/12

\section{Dear Editor}
please find enclosed the revised version of the manuscript APYA-D-12-00685 "A XANES study of chromophores in archaeological glass." by Rossella Arletti, Simona Quartieri and lan Freestone, modified after the reviewers' comments.
All the points raised by the reviewers are commented in the following.
Editor:
The manuscript may look just as "another paper reporting the study of ancient glasses from other provenances" once the novelty eventually contained in the submitted manuscript is not dully emphasized. Beyond complementing the reported chemical data, a more detailed physical discussion of XANES results would help support the submission of the manuscript to Applied Physics A, Materials Science \& Processing. -A table with the whole chemical analyses of all the samples was provided -some more details have been added to the description of the method adopted for the determination of Fe oxidation state. 
Reviewer \#1:

Page 2, line 57-58: It would benefit the readers to include a reference of using arsenic to control the color due to Fe oxidation state as I found it is less common than antimony and manganese for the same role.

-As far as we are aware, arsenic was not used regularly as a decolorant in glass until the eighteenth century AD in Bohemia. It was used on a regular basis in the nineteenth century (see Dungworth D, 2011. The Value of Historic Window Glass. The Historic Environment 2, 21-48). This reference has been added to the manuscript.

Page 3, line 26: Please delete a space before the last bracket.

- The text was corrected according to the referee suggestion

Page 3, line 30: Please use a comma between 20 and 21.

- The text was corrected according to the referee suggestion

Page 4, line 13: The authors used the word "essentially similar technology" referring to a technology applied for production of most glass from the Roman world. This word is rather general and don't provide additional information to the readers. It would be better to describe it or give some reference

-The text has been expanded slightly and rearranged to provide more information

Page 4, line 19: For clarity, please replace "This" with "This workshop".

- The text was corrected according to the referee suggestion

Page 4, line 30-34: The authors suggested a possibility of the furnace having failed towards the end of its life based on color of glass remains. This is very interesting point, but it would be supportive to describe the structure of the furnace, assuming that the authors have investigated the furnace, to understand how the oxygen could leak in, or how it prevented oxygen during its working stage.

-The text has been expanded slightly and rearranged to provide more explanation

Page 4, line 37: Please provide concentration of titanium in the third group of samples studied which were classified as HIMT glass, or at least a range of Ti concentration. -A table with the whole chemical analyses of all the samples has been included in the manuscript

Page 4, line 59: The authors wrote that Fe and Mn K-edge XANES spectra were collected during two different experiments. Did it mean the Fe spectra were collected using $\mathrm{Si}(311)$ and $\mathrm{Mn}$ ones using $\mathrm{Si}(111)$ crystals?

-Most of the samples (both Fe and Mn K-edges) were collected using a Si(311) crystal. Few samples were collected in a following experiment where only Si(111) was available.

Page 5, line 2: The authors used the photon energy of $7111.5 \mathrm{eV}$ as the first inflection point seen in an Fe-foil XANES spectrum for calibrating the monochromotor. The actual value should be $7112 \mathrm{eV}$. Although it will not affect their analysis as the energy shift due to oxidation state was measured relative to this position, but it is more correct to use the real value.

We are aware that $7112 \mathrm{eV}$ is the actual value of the edge, but, having collected the Fe-foil simultaneously with the samples, and resulting all the foil edges at the same energy position $(7111.5 \mathrm{eV})$, we decided to keep this as the reference value. This choice is, on the other hand, largely adopted in literature.

Page 5, line 10: Replace "XAFS" with "XANES".

-The text was corrected according to the referee suggestion

Page 5, line 21: Please give a reference to the program PeakFit4.

-The reference has been added in the text

Page 5, line 26: Is the uncertainty $\pm 0.02 \mathrm{eV}$ of the centroid obtained from the fit ? How about the uncertainty of the monochromator (photon energy) after calibration? Is this 
corrected by measuring a foil placed behind each sample as previously referred to the internal calibration?

- The uncertainty of the monochromator was checked by measuring a foil placed behind each sample. The uncertainty in the energy position of the centroid was estimated by comparing several fit tests.

Page 6, line 2-10: The explanation on how " I(Fe3+)/[I(Fe2+)+I(Fe3+)]" determined is clear enough, but not the "Fe3+\% from XANES" with the corresponding values listed in the last column of the Table 3. Please explain it.

After this comment, the text and the table were changed.

Page 6, line 43: Please delete a space between "is" and a comma.

- The text was corrected according to the referee suggestion

Figure 4: There are 16 samples in the plot, but 15 samples in the Table 1. Is one of them missing?

-The plot was corrected, the number of samples is 15

Table 1: For not to be mistaken between "not determined" and "not detected", please define "n.d."

-A new table (1) with the whole chemical data was added. The explanation of the abbreviation is given in the caption,

\section{Reviewer \#2:}

The content and layout of the manuscript are in line with previous papers published by the two first Authors in Archaeometry-focused Journals - namely, references [3$6],[15,16],[22]$. Beyond a few specific suggestions that follow, a more detailed physical discussion of XANES data is recommended for a publication in Applied Physics A. -The XANES data analysis applied in this work is conventional and reported in details in other papers cited here; however, some more details have been added to the description of the method adopted for the determination of Fe oxidation state.

1. Only eight glasses are reproduced in Fig. 1, some with greenish and bluish tonalities; has the bulk chemistry of the glasses been studied? Indeed, to complement the data listed in Table 1 additional chemical information is required concerning the occurrence of other chromophores, particularly copper.

-The detailed chemical analyses was added to the paper, unfortunately, not all the chromophores were analyzed in these specific samples. However, the contexts of the samples and the analyses of closely related material from the same contexts indicate that, apart the North Sinai sample 22, which is cobalt blue, copper and cobalt are present in trace amounts only.

2. To quote the coordination $\mathrm{VI}$ for $\mathrm{Mn}$ in Table 2 is not enough once the geometry of the coordination environment varies for the listed model minerals (as clearly reflected in the pre-edge details of Mn K-edge XANES spectra reproduced in Fig. 3).

-We are aware that the coordination geometry has an effect on the XANES signal and in fact we have selected several reference compounds containing $\mathrm{Mn}$ in different octahedral coordination geometry. However, it must be underlined that, in the present study, we are more interested in the cation oxidation state than in its coordination geometry.

3. Suggestion of a few specific corrections:

- Introduction, p.2, lines 7-8: correct the statement, once the nature of coordinating atoms needs to be known a priori for a full exploitation of XAS data on the absorbing coordinated element - "information about a specific absorbing element: oxidation state, site symmetry, number of surrounding atoms"

-The text has been modified receiving the referee comment. However, it should be noted that with XAS technique (in particular with the study of the EXAFS region of the absorption spectrum), it is also possible to investigate the chemical nature of the neighboring atoms.

- Id., lines 29-30: summarize the references - (e.g., 3 - 22)

-Unfortunately, the software we have used to write the manuscript does not allow summarizing the references. 
We sincerely thank the two referees and the Editor for their review work and useful suggestions. We hope the manuscript is now suitable for publication on APA.

Best regards

Rossella Arletti 


\title{
A XANES study of chromophores in archaeological glass
}

\section{Rossella Arletti ${ }^{1}$, Simona Quartieri ${ }^{2}$ and Ian C. Freestone ${ }^{3}$,}

\author{
${ }^{1}$ Dipartimento di Scienze della Terra, Università di Torino, via Valperga Caluso 35, 10125 Torino, \\ Italy \\ ${ }^{2}$ Dipartimento di Fisica e Scienze della Terra, Università di Messina, Viale Ferdinando Stagno \\ d'Alcontres 31, 98166 Messina S'Agata, Italy \\ ${ }^{3}$ Institute of Archaeology, 31-34 Gordon Square, London WC1B 3DG, UK
}

Running title: XANES study of chromophores in ancient glass

\section{Corresponding author:}

\author{
Rossella Arletti \\ Dipartimento di Scienze della Terra, Università di Torino \\ Via Valpega Caluso, 3510125 Torino \\ E-mail: rossella.arletti@unito.it \\ Phone: +390116705122 \\ FAX:+390116705128
}




\section{ABSTRACT}

We applied X-ray Absorption Near Edge Spectroscopy (XANES) to obtain information on the origin of glass color of several archaeological samples and on the oxidation conditions employed during their production. We studied a series of selected glass fragments - mainly from excavated primary and secondary production centers and dated to the first millennium AD - containing iron and manganese in a wide compositional range. In most of the studied samples iron is rather oxidized, while Mn K-edge XANES data show that, in all the studied glass, Mn is mainly present in its reduced form (predominantly 2+), with the possible subordinate presence of $\mathrm{Mn}^{3+}$.

The most oxidized samples are the HIMT (High Iron Manganese Titanium) glasses, while the less oxidized belong to the primary natron glass series from the early Islamic tank furnaces at Bet Eliezer (Israel), and to the series coming from a Roman glass workshop excavated in Basinghall Street, London. In these glasses, iron is approximately equally distributed over the $2+$ and $3+$ oxidation states. The XANES analyses of two glass which had been deliberately decolorized using $\mathrm{Sb}$ - and Mn-based decolorizers, demonstrate that $\mathrm{Sb}$ is more effective than $\mathrm{Mn}$ as oxidant.

\section{KEY-WORDS:}

Archaeological glass, XANES, color, chromophores, iron, manganese

\section{INTRODUCTION}

The elemental composition of early glass is frequently determined in archaeometric studies, in order to obtain information on the raw materials and on their provenance. Less frequently, the oxidation conditions of the glass production are investigated. Actually, the evaluation of the oxidation state of coloring elements in ancient glass offers important information not only about the origin of color, but also on the production technology applied in ancient times. Beyond the choice of the raw materials, oxygen fugacity is one of the parameters which had to be carefully controlled by the ancient glass workers, as this variable was extremely important in determining the final glass color. It is well known, in fact, that the color of glass is largely controlled by the oxidation state and the coordination geometry of the metal ions dispersed in the glass matrix, whether their presence is intentional or unintentional.

Early glass typically contains $0.3 \%$ or more iron oxide, which is able to colour the glass quite strongly, even under moderately reducing conditions. Early glassmakers made various attempts to control the colour due to Fe oxidation state by adding oxides of polyvalent metals, including manganese, antimony and, in the early modern period, arsenic [1]. Thus, if we want to 
understand the practices of the ancient glass workers and the extent of their control on the final glass colours, we need to systematically study the oxidation state of the glass chromophores.

X-ray Absorption Spectroscopy (XAS) is a widely applied technique, able to provide information on iron oxidation states and offers the advantage of being non-destructive, elementselective and sensitive to low concentrations of dilute species. In general, it can provide structural information about a specific absorbing element: oxidation state, site symmetry, number of the surrounding atoms, inter-atomic distances and disorder parameters of the first few coordination shells. In particular, in the X-ray Absorption Near Edge Spectroscopy (XANES) region of the absorption spectrum (conventionally taken to be within about $50 \mathrm{eV}$ from the absorption edge), characteristic spectral features in the vicinity of the absorption edge are observed. These are due to the electronic transitions from core levels to unoccupied (bound or unbound) final states. These spectral features provide information on the site coordination, symmetry and distortion, and on the oxidation state of the central absorbing atom. A further important characteristic of this spectroscopic technique is its applicability to both crystalline and amorphous materials. For all these reasons, XANES has been successfully applied to a number of archaeological studies (see e.g. 2,3 for a review).

Concerning Fe-bearing glass of geological or archaeological interest, several XANES studies are reported in literature [e.g. 4,5,6,7,8,9,10,11,12,13,14,15,16,17,18,19,20,21,22,23]. XANES spectroscopy has also been successfully applied to the speciation of Mn in minerals and glass [e.g. $24,25,26])$, in spite of the difficulties connected with the common co-existence of different oxidation states of this element $(2+, 3+, 4+)$. In particular, XANES studies of $\mathrm{Mn}$ in ancient glass were performed to understand whether this element was present as an impurity in the raw materials or intentionally added to the batch as a decoloring agent (e.g. [6,16,23]. It is, in fact, well known that in ancient times Mn was added as pyrolusite to the batch to control the final color of the glass by means of a redox reaction in which $\mathrm{Mn}^{4+}$ reduces while $\mathrm{Fe}^{2+}$ oxidizes - neutralizing the effect of $\mathrm{Fe}^{2+}$ contained in the heavy minerals present as impurities in the sand, and imparting the typical yellow-green color to the artifacts. Since iron is always present in the ancient glass at measurable concentrations, $\mathrm{Fe}^{3+} / \mathrm{Fe}^{2+}$ ratio is an appropriate index to compare the oxidation conditions of large suites of archaeological samples .

The present paper reports the study of the oxidation conditions of a number of glass finds of the natron type. Natron was a source of sodium carbonate which was found primarily in lakes in the Wadi Natrun and the Nile Delta of Egypt. It was used as a key glass constituent throughout the first millennia BC and AD and is particularly characteristic of Roman glass, the great majority of which was made using natron as a flux. The color of all of the samples here studied derives predominantly 
from the $\mathrm{Fe}^{3+} / \mathrm{Fe}^{2+}$ ion ratio. This ratio can be determined by i) the raw materials; ii) the furnace

atmosphere and melting duration; and iii) any addition of antimony or manganese oxides made to deliberately decolorize the glass by means of iron oxidation.

\section{THE ARCHAEOLOGICAL GLASS}

The analysed samples fall into three groups. A first group of raw glass chunks from Bet Eli'ezer, (Israel, 7-8th centuries AD) - labelled "BET EL" in Table 1 - are derived from a group of primary tank furnaces on the coastal plain of Israel [27]. It is believed that most glass from the Roman world was produced in this region, using an essentially similar technology where mineral soda and sand were melted together in large tanks with capacities of 8 tonnes or more [27]. Five samples were chosen to give the production color range. A second group of samples are from the excavation of a Roman secondary glass workshop, in Basinghall Street, London (2nd- 3rd centuries AD) - labelled "BAS" in Table 1. This workshop used both fresh glass from Palestine and recycled cullet as raw material. The analysed samples were selected to represent a series of stages in the life of the workshop, to determine if significant changes in redox conditions in the furnace occurred. They include raw glass, thought to be imported (BAS 4), and a number of moils, which are the glass remains left around the blowpipe end when a vessel was blown. Among these, two colourless samples - which appear to have been deliberately decolorised by the addition of $\mathrm{MnO}_{2}$ (BAS 47) and $\mathrm{Sb}_{2} \mathrm{O}_{5}$ (BAS 46) - were included. The clay superstructure of the reverbatory tank furnace appears to have failed towards the end of its life, allowing air into the melting chamber and oxidising the surface layers of the tank of glass from blue to green. This supposedly “oxidised" glass is represented by sample BAS 71 .

A third sample group represents the so-called HIMT glass, (4th-5th centuries AD), which is high in iron, manganese and titanium. HIMT has been suggested to originate in Roman Egypt [28]. One of the HIMT glass here studied was found in Carthage [29] and the other two in the North Sinai [30]. Sample NS 6830-22 differs from the others in this study in that it has been deeply coloured by the addition of cobalt.

In addition, to test the origin of its colour, a chunk of purple plant ash glass from the early Islamic site of Banias, Israel [26] with high levels of deliberately added manganese, was added to the samples set. Table 2 reports the chemical data relative to major and minor elements of all the analysed samples

\section{EXPERIMENTAL METHODS}

X-ray Absorption Spectroscopy 
Fe and Mn $K$-edge XANES spectra were collected in fluorescence mode at the GILDA-CRG

beamline (ESRF, Grenoble, France), during two different experiments, using a dynamically and sagittally focussing monochromator [31], with $\mathrm{Si}(311)$ and $\mathrm{Si}(111)$ crystals, respectively. For all spectra, a reference metallic foil was used to provide an internal and accurate energy calibration of the monochromator. The position of the first inflection point was taken at 7111.5 and $6538.0 \mathrm{eV}$ for Fe and Mn foil, respectively. The vertical dimension of the investigated regions was about $1 \mathrm{~mm}$, while the horizontal one ranged between $2 \mathrm{~mm}$ and $5 \mathrm{~mm}$. Beyond the glass samples under study, several model compounds containing iron and manganese in different oxidation states and local geometries were also studied by XANES spectroscopy (see Table 3). All reference compounds [23] were finely ground and deposited on Millipore membranes using alcohols, otherwise the sample spectra were collected directly on the glass fragments. All the XANES spectra were collected at room temperature. The pre-edge background was subtracted and then the spectra of samples and reference compounds were normalized on the high-energy side of the curve. The pre-edge region was then extracted and analysed by least-square fitting of pseudo-Voight functions (sum of Gaussian and Lorentzian functions) to the pre-edge spectral envelope, using the program PeakFit4 [32]. For each sample, the pre-edge centroid was calculated from the average position of the pseudo-Voigt functions, weighted by their respective integrated areas. The estimated error on the centroid position is \pm 0.02 . The total integrated area is the sum of the individual integrated areas.

The Fe and Mn pre-edge deconvolution of reference compounds and of samples in Fig. 2 and 3. The numerical results of the detailed study of the Fe and Mn $K$-edge XANES pre-edges are reported in Table 3 for the reference compounds and in Table 4 for the glass samples.

\section{RESULTS}

It is well known that the Fe $K$-edge XANES spectra display a number of features which may be attributed to transitions between bound electronic states and which shift to higher energies with increasing oxidation state. In particular, the intensity of the pre-edge peak varies considerably as a function of the coordination environment and symmetry, while the pre-edge energy position is strongly influenced, besides the bond distances, by the oxidation state, being the centroid of the pre-edge peak of the $\mathrm{Fe}^{3+}$ rich minerals and glass varieties shifted towards higher energy with respect to those containing iron in the reduced form $[19,21,33,34,35,36]$. Hence, the centroid energy position is largely used in literature for estimating iron oxidation state. Moreover, as discussed by Wilke et al. [19], the evaluation of Fe oxidation state in glass and melts can be improved measuring not only the pre-edge centroid position, but also the intensity values at energy positions corresponding to the peak positions of $\mathrm{Fe}^{3+}$ and $\mathrm{Fe}^{2+}$, respectively. Specifically, good 
results were achieved using the ratios of the intensities measured at these energy positions.

Following the procedure adopted in [19] - after determining the centroid energy positions the pre-edge peak intensities were also calculated by integrating the extracted pre-edge spectra in two energy ranges: (i) between 7113.5 and $7114.5 \mathrm{eV}$ for the contribution of $\mathrm{Fe}^{3+}$ : $\mathrm{I}\left(\mathrm{Fe}^{3+}\right)$ and (ii) between 7111.7 and $7112.7 \mathrm{eV}$ for the contribution of $\mathrm{Fe}^{2+}: \mathrm{I}\left(\mathrm{Fe}^{2+}\right)$. The ratio between the intensities relative to $\mathrm{Fe}^{3+}$ and the total iron $\left(\right.$ i.e. $\left.\mathrm{I}\left(\mathrm{Fe}^{3+}\right) /\left[\mathrm{I}\left(\mathrm{Fe}^{2+}\right)+\mathrm{I}\left(\mathrm{Fe}^{3+}\right)\right]\right)$ was then calculated. The percentages of $\mathrm{Fe}^{3+}$ in the glass samples was then calculated by these intensity ratios, on the basis of a calibration curve obtained by the references compounds, and then reported in the last column of Table 4. Figure 4 reports the plot of $\mathrm{I}\left(\mathrm{Fe}^{3+}\right) /\left[\mathrm{I}\left(\mathrm{Fe}^{2+}\right)+\mathrm{I}\left(\mathrm{Fe}^{3+}\right)\right]$ $v s$. the pre-edge centroid positions, and shows the good correlation between the results of the two XANES-based methods suitable for estimating iron oxidation state.

Mn $K$-edge XANES spectra of our glass samples are all very similar . The pre-edge fits (Figures 3b) and the energy position of the pre-edge centroids (Table 4) are very similar to those of the reference compounds rhodocrosite and $\mathrm{MnO}$ (Fig. 3a and Table 3) which contain $\mathrm{Mn}$ in the 2+ oxidation state. On the contrary, all the XANES features of pyrolusite $\left(\mathrm{Mn}^{4+} \mathrm{O}_{2}\right)$ are shifted by a few $\mathrm{eV}$ towards higher energy. These data suggest that, in all the studied glasses, $\mathrm{Mn}$ is mainly present in its reduced form, in agreement with the results discussed in literature - see [25] for a review which report that the high oxidation states of $\mathrm{Mn}$ are normally not present in glass because they are unstable at the temperatures at which it is produced. The presence of a subordinate amount of $\mathrm{Mn}^{3+}$ cannot, however, be excluded, as discussed in [23]. These authors studied a series of Late Roman glass fragments belonging to the HIMT group - coming from archaeological sites in Italy - by means of a multi-spectroscopic approach. They showed that, notwithstanding Mn $K$-edge XANES data suggested the predominant presence of $\mathrm{Mn}^{2+}$ in all samples, UV-VIS investigations revealed the presence of minor amounts of strongly coloring $\mathrm{Mn}^{3+}$ in some purple glass.

\section{DISCUSSION}

The analysis of the Fe $K$-edge XANES pre-edge peaks (Table 4 and Fig. $2 b$ ) indicates that in most of the 15 glass samples here studied iron is rather oxidized. In fact, the position of the preedge peak centroid is, for many samples, at higher energy with respect to the standard glass ST1, containing about $70 \%$ of $\mathrm{Fe}^{3+}$.

The most oxidized samples are the HIMT glasses (Carthage, NS 6830-27) the plant ash glass from Banias, and BAS 46 and 47, the colourless glasses from the glass workshop in Basinghall Street, London. Iron oxidation in the fourth century HIMT samples is probably obtained by the deliberate addition of $\mathrm{MnO}_{2}$, since the amounts of this oxide deriving from the 
chemical analysis are not consistent with its presence as impurity in the raw materials. The strong

color of these samples is due to the combination effect of the presence of overall high $\mathrm{Fe}$ and $\mathrm{Mn}$ contents.

It is interesting to note that the two glass from North Sinai (NS 6830-27 and 6830-22) are characterized by a different iron oxidation degree (Table 4). In particular, in NS 6830-22 - which is cobalt blue - iron is more reduced. This could be ascribed to the deliberate addition of Co-bearing materials (for instance sulphide), which induced - as a secondary effect - the iron partial reduction.

Concerning BAS 46 and BAS 47 samples, it is interesting to note that both were deliberately decolorized, using antimony- and manganese-based decolorizes, respectively. However, the Mn-decolored glass (BAS 47) looks slightly greenish, while the Sb-decolored one (BAS 46) looks completely uncoloured. This suggests that $\mathrm{Sb}$ is more effective than $\mathrm{Mn}$ as oxidant. This conclusion is consistent with the results of the XANES analysis, which shows that iron in BAS46 is more oxidized than in BAS47 (Table 4).

The less oxidized samples belong to the primary natron glass series from the early Islamic tank furnace at Bet Eliezer (Israel), (in particular, samples BET EL3, 4 and 239) and to the series of glass coming from the Roman glass workshop excavated in Basinghall Street, London (specifically, samples BAS4, 56, 63 and 71). In these findings, iron is approximately equally distributed over the $2+$ and $3+$ oxidation states. The presence of partially reduced iron in sample BAS 71 is in contrast with its colour, which was supposed to be due to the oxidised species. It is interesting to note that the bluish glass BET EL 2 - showing a significant level of $\mathrm{Fe}^{3+}(68 \%)$ - has essentially the same elemental composition as the greenish/olive (BET EL 3) and the brown (BET EL 4) samples, which are, on the contrary, more reduced. This suggests that these last two glasses were produced in furnace regions with less access to air. Concerning the amber glass BET EL 239, it is the most reduced among the BET EL samples.

Finally, the XANES data on the chunk from Banias (Israel) indicate that iron is fully oxidized, as a result of the deliberate addition of a high amount of Mn dioxide. The purple color of this glass suggests the presence of $\mathrm{Mn}^{3+}$. However, other glasses (e.g. BAS 47, NS-6830-27) which have larger excesses of manganese over iron (Table 2) are not purple, suggesting that furnace atmosphere, as well as manganese content, may have influenced the oxidation state in this case.

Overall, these results suggest that primary natron glass was typically produced under moderately reducing conditions, where $\mathrm{Fe}^{3+}$ represents $50-70 \%$ of the total iron. More oxidised glasses appear to have been produced by adding an oxidising agent such as manganese or antimony oxide to the glass. The results from the workshop at Basinghall Street suggest that remelting and 
blowing the primary glass into vessels had a relatively minor effect on its oxidation state. Further work on well-contextualised material is needed to clarify these issues.

\section{ACKNOWLEDGEMENTS}

The authors are grateful to BM08 GILDA beamline staff (ESRF, Grenoble) for the assistance during the XANES experiments. 


\section{Figure captions}

Figure 1 - Picture of selected glass samples.

Figure 2 - Normalized Fe $K$-pre-edge spectra and the best fit model calculated for (a) the reference compounds and (b) the glass samples.

Figure 3 - Normalized Mn $K$-pre-edge spectra and the best fit model calculated for (a) the reference compounds and (b) the glass samples.

Figure 4 - Plot of $\mathrm{I}\left(\mathrm{Fe}^{3+}\right) /\left[\mathrm{I}\left(\mathrm{Fe}^{2+}\right)+\mathrm{I}\left(\mathrm{Fe}^{3+}\right)\right]$ vs. the pre-edge centroid positions, calculated by $\mathrm{Fe} \mathrm{K}$ edge XANES data. 
[1]D.Dungworth, The Historic Environment 2, 21 (2011)

[2] M. Cotte, J. Susini, J. Dik, K. Janssens, Accounts Chem. Res. 43, 705 (2010)

[3] S. Quartieri S. (2011) Synchrotron Radiation in Archaeological and Cultural Heritage Science. XI School on Synchrotron Radiation: Fundamentals, Methods and Applications. Duino (Trieste Italy) 5 - 16 September 2011, http://webusers.fis.uniroma3.it/sils/apertura.htm.

[4]R. Arletti, M.C. Dalconi, S.Quartieri, M. Triscari, G. Vezzalini, Appl. Phys. A 83, 239 (2006)

[5]R. Arletti R, G. Vezzalini, S. Quartieri, D. Ferrari, M. Merlini, M. Cotte, Appl. Phys. A 92, 127 (2008)

[6] R. Arletti, C. Giacobbe, S. Quartieri, G. Sabatino, G. Tigano, M. Triscari, G. Vezzalini, Archaeom. 52, 99 (2010)

[7] R. Arletti, R., G. Vezzalini, S. Benati, L. Mazzeo Saracino, A. Gamberini, Arch. 52, 252 (2010)

[8] F. Farges, Y. Lefrere. S. Rossano, A. Berthereau, G. Calas, G.E. Brown, J. Non-Cryst. Solids, 344, $176(2004)$

[9] F. Farges, E. Chalmin, C. Vignaud, I. Pallot-Frossard, J. Susini, J. Bargar, G.E. Brown, M. Menu, Phys. Scripta 115, 885 (2005)

[10] F. Farges, S. Djanarthany, S. de Wispelaere, M. Munoz, B. Magassouba, A. Haddi, M. Wilke, C. Schmidt, M. Borchert, P. Trocellier, W. Crichton, A. Simionovici, P.E. Petit, M. Mezouar, M.P. Etcheverry, I. Pallot-Frossard, J.R. Bargar, G.E. Brown, D. Grolimund, A. Scheidegger, Phys. Chem. Glasses, 46, 350 (2005)

[11] L. Galoisy, G., Calas, M.A. Arrio, Chem. Geol., 174, 307 (2001).

[12] G. Giuli, G. Pratesi, C. Cipriani, E. Paris, Geochim. Cosmochim. Ac. 66, 4347 (2002)

[13] G. Giuli, S.G. Eeckhout, E. Paris, C. Koeberl, G. Pratesi, G. Meteorit. Planet. Sci., 40, 1575 (2005)

[14] G. Giuli, S.G. Eeckhout, C. Koeberl, G. Pratesi, E. Paris, . Meteorit. Planet. Sci. 43, 981 (2008)

[15] N. Métrich, J. Susini, E. Foy, F. Farges, D. Massare, L. Sylla, S. Lequien, M. Bonnin-Mosbah, Chem.Geol. 231, 350 (2006)

[16] S. Quartieri, M. Triscari, G. Sabatino, F. Boscherini, A. Sani A. Eur. J. Mineral. 14, 749 (2002):

[17] S. Quartieri, M.P. Riccardi, B. Messiga, F. Boscherini, J. Non-Cryst. Solids, 351, 3013 (2005):

[18] S. Rossano, A. Ramos, J.-M Delaye, S. Creux, A. Filipponi, C.H. Brouder, G. Calas, Europhys. Lett. 49, 597 (2000)

[19] M. Wilke, G.M. Partzsch, R. Bernhardt, D. Lattard, Chem. Geol., 213, 71 (2004)

[20] M. Wilke, G. Schmidt, F. Farges, V. Malavergne, L. Gautron, A. Simionovici, M. Hahn, P.E. Petit, Chem. Geol., 229, 144 (2006)

[21] M.Wilke, F. Farges, G.M. Partzsch, C. Schmidt, H. Beherens, H, Am. Mineral. 92, 44 (2007)

[22] A. Santagostino Barbone, E. Gliozzo, F. D'acapito, I. Turbanti Memmi, M. Turchiano, G.Volpe, Archaeom. 50, 389 (2010)

[23] L. De Ferri, R. Arletti, G. Ponterini, S. Quartieri, Eur. J. Mineral. 23, 969 (2011)

[24] E. Chalmin, F. Farges, G.E. Brown, Contrib. Mineral. Petrol. 157, 111 (2009)

[25] O. Schalm, K. Proost, K. De Vis, S. Cagno, K. Janssens, F. Mees, P. Jacobs, J. Caen, Arch. (2010) doi: 10.1111/j.1475-4754.2010.00534.x

[26] S. Cagno, G. Nuyts, S. Bugani, K. De Vis, O. Schalm, J. Caen, L. Helfen, M. Cotte, P.

Reischig, K. Janssens, J. Anal. At. Spectrom. 26, 2442 (2011)

[27] I.C. Freestone, Y. Gorin-Rosen Y., M.J. Hughes in Ateliers primaires et secondaires de verriers du second millinaire av. J.-C. au Moyen-Age, ed. By M.-D. Nenna (Travaux de la Maison de l'Orient Méditerranéen 2000) p. 65

[28]I.C. Freestone, S.Wolf, M. Thirlwall, Annales du 16e Congres de 1'Association Internationale pour l'Histoire du Verre, 153 (2005) 
[29] I.C. Freestone, I.C. 1994, in Excavations at Carthage, Vol II, ed. By H. Hurs (Oxford Univ Press for British Academy. 1994), p. 290.

[30] I.C. Freestone, R. Greenwood, Y. Gorin-Rosen in Hyalos - Vitrum - Glass. History Technology and Conservation of glass and vitreous materials in the Hellenic World. 1st International conference Rhodes - Greece, ed. By G. Kordas (2002) p. 167.

[31] S. Pascarelli, F. Boscherini, F. D’Acapito, J. Hardy, C. Meneghini, S. Mobilio, J. Synch. Rad. 3, 147 (1996)

[32] PeakFit4 - Systat Software.Inc, www.systat.com/products/PeakFit/

[33] A.J. Berry, H.St.C. O’Neill, K.D. Jayasuriya, S.J. Campbell, G.J. Foran, Am. Mineral., 88, 967 (2003)

[34] M. Wilke, F. Farges, P.E. Petit, G.E. Brown, F. Martin, Am. Mineral. 86, 714 (2001)

[35] G.A. Waychunas, M.J. Apted, G.E. Brown, Phys. Chem. Min. 10, 1 (1983)

[36] T.E. Westre, P. Kennepohl, J. de Witt, B. Hedman, K.O. Hodgson, E.I., Solomon, J. Am. Chem. Soc. 119, 6297 (1997) 
Table 1 - Selected information on provenance, color, typology and chemistry of the studied ancient glass samples.

\begin{tabular}{llll}
\hline Sample & Provenance & Color & Description \\
\hline BET EL 6831-1 & Bet Eliezier & Blue green & Chunk from tank furnace \\
BET EL 2 & Bet Eliezier & Blue green & Chunk from tank furnace \\
BET EL 3 & Bet Eliezier & Green & Chunk from tank furnace \\
BET EL 4 & Bet Eliezier & Brown & Chunk from tank furnace \\
BET EL 239 & Bet Eliezier & Amber & Chunk from tank furnace \\
BAS 4 & London & Green-blue & Lump of raw glass \\
BAS 46 & London & Colorless & Moil \\
BAS 47 & London & Colorless & Moil \\
BAS 56 & London & Green blue & Moil \\
BAS 63 & London & Green blue & Moil \\
BAS 71 & London & Yellow-green & Moil \\
Carthage & Carthage & Green-olive & Chunk \\
\hline NS 6830-27 & North Sinai & Green -olive & Chunk from tank furnace \\
\hline NS 6830-22 & North Sinai & Cobalt blue & Vessel \\
\hline Banias & Banias & Purple & Chunk from tank furnace \\
\hline
\end{tabular}


Table 2: Chemical data of the analysed samples. All the data are reported as wt \% with the exclusion of $\mathrm{Cu}$ and $\mathrm{Co}(\mathrm{ppm})$

Abbreviations: b.d.: below detection limit, n.a.: not analysed

\begin{tabular}{|c|c|c|c|c|c|c|c|c|c|c|c|c|c|c|c|}
\hline Sample & $\mathrm{SiO}_{2}$ & $\mathrm{TiO}_{2}$ & $\mathrm{Al}_{2} \mathrm{O}_{3}$ & MgO & MnO & $\mathrm{Fe}_{2} \mathrm{O}_{3}$ & $\mathrm{CaO}$ & $\mathrm{Na}_{2} \mathrm{O}$ & $\mathrm{K}_{2} \mathrm{O}$ & $\mathbf{C l}$ & $\mathrm{SO}_{3}$ & $\mathbf{P}_{2} \mathrm{O}_{5}$ & $\mathrm{Sb}_{2} \mathrm{O}_{3}$ & $\mathrm{Cu}$ ppm & Co ppm \\
\hline BET EL 6831-1 & 75.98 & $<0.10$ & 3.29 & 0.57 & 0.02 & 0.49 & 5.96 & 12.14 & 0.40 & 0.70 & 0.15 & $<0.10$ & n.d. & 9 & 1 \\
\hline BET EL 2 & 73.65 & 0.16 & 3.70 & 0.68 & 0.02 & 0.94 & 6.65 & 13.01 & 0.55 & 0.54 & 0.12 & $<0.10$ & $<0.1$ & 21 & 2 \\
\hline BET EL 3 & 74.95 & 0.13 & 3.36 & 0.58 & 0.02 & 0.58 & 7.27 & 11.36 & 0.46 & 0.68 & 0.14 & $<0.10$ & $<0.1$ & 25 & 1 \\
\hline BET EL 4 & 75.98 & $<0.10$ & 3.06 & 0.61 & 0.01 & 0.39 & 7.63 & 11.27 & 0.43 & 0.69 & 0.18 & $<0.10$ & $<0.1$ & 9 & 2 \\
\hline BET EL 239 & 72.85 & 0.12 & 3.63 & 0.51 & $<0.10$ & 0.64 & 7.98 & 13.04 & 0.47 & 0.79 & $<0.1$ & $<0.10$ & $<0.1$ & n.a. & n.a. \\
\hline BAS 4 & 70.85 & 0.05 & 2.19 & 0.51 & 0.26 & 0.42 & 8.29 & 15.11 & 0.66 & 0.99 & 0.23 & 0.21 & b.d. & 3 & 3 \\
\hline BAS 46 & 68.96 & 0.03 & 1.66 & 0.40 & 0.01 & 0.42 & 6.37 & 19.06 & 0.38 & 1.36 & 0.40 & 0.04 & 0.79 & 13 & 2 \\
\hline BAS 47 & 70.29 & 0.02 & 2.15 & 0.56 & 1.34 & 0.31 & 7.90 & 15.57 & 0.54 & 1.11 & 0.19 & 0.10 & b.d. & 18 & 11 \\
\hline BAS 56 & 70.88 & 0.09 & 2.41 & 0.51 & 0.52 & 0.46 & 7.50 & 15.94 & 0.60 & 1.02 & 0.24 & 0.06 & b.d. & 37 & 10 \\
\hline BAS 63 & 70.49 & 0.10 & 2.31 & 0.41 & 0.54 & 0.31 & 7.96 & 16.25 & 0.44 & 1.21 & 0.30 & -0.01 & b.d. & 3 & 6 \\
\hline BAS 71 & 70.37 & 0.14 & 2.41 & 0.54 & 0.51 & 0.48 & 7.50 & 15.13 & 0.57 & 1.04 & 0.18 & 0.05 & 0.62 & 28 & 11 \\
\hline Carthage 32832 & 64.23 & 0.71 & 3.28 & 1.21 & 1.6 & 3.65 & 5.00 & 18.39 & 0.46 & 1.03 & 0.14 & $<0.10$ & $<0.1$ & 65 & 14 \\
\hline NS 6830-27 & 66.08 & 0.36 & 2.49 & 1.14 & 2.63 & 1.33 & 5.56 & 17.58 & 0.47 & 0.96 & 0.35 & $<0.10$ & $<0.1$ & 65 & 11 \\
\hline NS 6830-22 & 65.69 & 0.39 & 2.67 & 1.14 & 0.42 & 2.42 & 5.98 & 17.95 & 0.49 & 0.97 & 0.44 & $<0.10$ & $<0.1$ & $\sim 0.1$ & $\sim 0.1$ \\
\hline Banias 62 & 71.70 & 0.19 & 0.87 & 2.71 & 0.95 & 0.36 & 7.61 & 12.76 & 1.84 & 0.88 & 0.27 & 0.27 & b.d. & n.a. & 4 \\
\hline
\end{tabular}


Table 2 - Fe and Mn K-edge XANES feature positions of the reference compounds.

\begin{tabular}{|c|c|c|c|c|c|c|c|}
\hline Sample & $\begin{array}{c}\text { Fe } \\
\text { oxidation } \\
\text { state }\end{array}$ & Coordination & $\begin{array}{l}\text { Component } \\
\text { position }(\mathrm{eV})\end{array}$ & Area & $\begin{array}{l}\text { Total } \\
\text { Area }\end{array}$ & $\begin{array}{c}\text { Centroid } \\
\text { position } \\
(\mathrm{eV})\end{array}$ & $\mathbf{R}^{2}$ \\
\hline Almandine & $2^{+}$ & VIII & $\begin{array}{l}7112.30 \\
7113.92\end{array}$ & $\begin{array}{l}0.0252 \\
0.0079\end{array}$ & 0.0332 & 7112.69 & 0.9976 \\
\hline Olivine & $2^{+}$ & VI & $\begin{array}{l}7111.73 \\
7112.50 \\
7113.77\end{array}$ & $\begin{array}{l}0.0192 \\
0.0097 \\
0.0051\end{array}$ & 0.0340 & 7112.25 & 0.9993 \\
\hline Hercynite & $2^{+}$ & IV & $\begin{array}{l}7112.25 \\
7113.67\end{array}$ & $\begin{array}{l}0.1232 \\
0.0520\end{array}$ & 0.1752 & 7112.67 & 0.9990 \\
\hline ST1 & $\begin{array}{l}33 \% 2^{+} \\
67 \% 3^{+}\end{array}$ & & $\begin{array}{l}7112.47 \\
7114.08\end{array}$ & $\begin{array}{l}0.0495 \\
0.0909\end{array}$ & 0.1404 & 7113.51 & 0.9992 \\
\hline Magnetite & $\begin{array}{l}2^{+} \\
3^{+}\end{array}$ & $\frac{\mathrm{VI}}{\mathrm{IV-VI}}$ & $\begin{array}{l}7113.31 \\
7113.94\end{array}$ & $\begin{array}{l}0.0339 \\
0.0877\end{array}$ & 0.1537 & 7114.06 & 0.9987 \\
\hline Hematite & $3^{+}$ & VI & $\begin{array}{l}7113.45 \\
7114.67 \\
7115.71 \\
7116.70 \\
7117.67\end{array}$ & $\begin{array}{l}0.0291 \\
0.0427 \\
0.0191 \\
0.0110 \\
0.0086\end{array}$ & 0.1106 & 7114.97 & 0.9997 \\
\hline Silicalite & $3^{+}$ & IV & 7114.18 & 0.3036 & 0.3036 & 7114.18 & 0.9979 \\
\hline Sample & $\begin{array}{c}\text { Mn } \\
\text { oxidation } \\
\text { state }\end{array}$ & Coordination & $\begin{array}{l}\text { Component } \\
\text { position }(\mathrm{eV})\end{array}$ & Area & $\begin{array}{l}\text { Total } \\
\text { Area }\end{array}$ & $\begin{array}{c}\text { Centroid } \\
\text { position } \\
(\mathrm{eV})\end{array}$ & $\mathbf{R}^{2}$ \\
\hline Rhodocrosite & $2+$ & VI & $\begin{array}{l}6539.21 \\
6540.05\end{array}$ & \begin{tabular}{|l|}
0.0206 \\
0.0184
\end{tabular} & 0.0390 & 6539.60 & 0.9985 \\
\hline Tephroite & $2+$ & VI & $\begin{array}{l}6538.83 \\
6539.50\end{array}$ & $\begin{array}{l}0.0261 \\
0.1174\end{array}$ & 0.1434 & 6539.38 & 0.9989 \\
\hline MnO & $2+$ & VI & $\begin{array}{l}6539.19 \\
6539.99\end{array}$ & $\begin{array}{l}0.0226 \\
0.0190\end{array}$ & 0.0416 & 6539.55 & 0.9985 \\
\hline $\mathrm{Mn}_{2} \mathrm{O}_{3}$ & $3+$ & VI & $\begin{array}{l}6539.55 \\
6541.30 \\
6542.74\end{array}$ & $\begin{array}{l}0.0570 \\
0.0305 \\
0.0232\end{array}$ & 0.1107 & 6540.70 & 0.9990 \\
\hline $\mathrm{MnO}_{2}$ & $4+$ & VI & $\begin{array}{l}6540.30 \\
6542.14 \\
6543.98\end{array}$ & $\begin{array}{l}0.0474 \\
0.0895 \\
0.0300\end{array}$ & 0.1668 & 6541.95 & 0.9986 \\
\hline
\end{tabular}


Table 3 - Fe and Mn K-edge XANES feature positions in the ancient glass samples.

\begin{tabular}{|c|c|c|c|c|c|c|c|}
\hline Sample & $\begin{array}{c}\text { Component } \\
\text { position }(e V)\end{array}$ & Area \% & Total Area & $\begin{array}{c}\text { Centroid } \\
\text { position }(e V)\end{array}$ & $\mathbf{R}^{2}$ & $\begin{array}{c}\mathbf{I}\left(\mathrm{Fe}^{3+}\right) /[\mathbf{I}( \\
\left.\mathrm{Fe}^{3+}\right)+ \\
\left.\left.\mathrm{I}^{3+} \mathrm{Fe}^{2+}\right)\right]\end{array}$ & $\mathrm{Fe}^{3+} \%$ \\
\hline \multicolumn{8}{|c|}{ Fe K-edge } \\
\hline \begin{tabular}{|l|} 
BET EL 6831-1 \\
\end{tabular} & $\begin{array}{l}7112.39 \\
7114.09\end{array}$ & $\begin{array}{l}28.462 \\
71.538\end{array}$ & 0.1578 & 7113.60 & 0.9996 & 0.690 & 70 \\
\hline BET EL 2 & $\begin{array}{l}7111.85 \\
7112.89 \\
7114.39\end{array}$ & $\begin{array}{l}11.525 \\
30.101 \\
58.373\end{array}$ & 0.1155 & 7113.65 & 0.9983 & 0.676 & 68 \\
\hline BET EL 3 & $\begin{array}{l}7112.16 \\
7113.13 \\
7114.40\end{array}$ & $\begin{array}{l}26.109 \\
31.843 \\
42.048\end{array}$ & 0.0886 & 7113.41 & 0.9986 & 0.582 & 56 \\
\hline BET EL 4 & $\begin{array}{l}7111.93 \\
7112.99 \\
7114.29\end{array}$ & $\begin{array}{l}24.664 \\
36.594 \\
38.742\end{array}$ & 0.08593 & 7113.23 & 0.9987 & 0.580 & 55 \\
\hline BET EL 239 & $\begin{array}{l}7111.78 \\
7112.82 \\
7114.20\end{array}$ & $\begin{array}{l}20.234 \\
42.417 \\
37.349\end{array}$ & 0.08210 & 7113.12 & 0.9995 & 0.510 & 46 \\
\hline BAS 4 & $\begin{array}{l}7112.00 \\
7112.99 \\
7114.29\end{array}$ & $\begin{array}{l}23.198 \\
32.567 \\
44.235\end{array}$ & 0.0991 & 7113.33 & 0.9995 & 0.580 & 55 \\
\hline BAS 46 & $\begin{array}{l}7112.80 \\
7114.08 \\
7114.99\end{array}$ & $\begin{array}{l}18.239 \\
45.514 \\
36.247\end{array}$ & 0.1212 & 7114.17 & 0.9994 & 0.879 & 96 \\
\hline BAS 47 & $\begin{array}{l}7112.47 \\
7114.19 \\
7115.11\end{array}$ & $\begin{array}{l}22.721 \\
55.787 \\
21.492\end{array}$ & 0.1437 & 7114.00 & 0.9992 & 0.749 & 78 \\
\hline BAS 56 & $\begin{array}{l}7111.90 \\
7113.04 \\
7114.19\end{array}$ & $\begin{array}{l}23.763 \\
34.702 \\
41.535\end{array}$ & 0.0774 & 7113.25 & 0.9990 & 0.566 & 54 \\
\hline BAS 63 & $\begin{array}{l}7111.87 \\
7112.79 \\
7114.20\end{array}$ & $\begin{array}{l}22.123 \\
33.698 \\
44.183\end{array}$ & 0.1110 & 7113.21 & 0.9991 & 0.545 & 51 \\
\hline BAS 71 & $\begin{array}{l}7111.92 \\
7112.77 \\
7114.19\end{array}$ & $\begin{array}{l}12.036 \\
38.291 \\
49.673\end{array}$ & 0.0708 & 7113.37 & 0.9991 & 0.586 & 56 \\
\hline
\end{tabular}




\begin{tabular}{|c|c|c|c|c|c|c|c|}
\hline Carthage & $\begin{array}{l}7112.53 \\
7114.12\end{array}$ & $\begin{array}{l}7.3259 \\
92.674\end{array}$ & 0.1797 & 7114.00 & 0.9993 & 0.883 & 96 \\
\hline NS 6830-27 & $\begin{array}{l}7112.68 \\
7114.05 \\
7114.42\end{array}$ & $\begin{array}{l}8.7434 \\
84.180 \\
7.0762\end{array}$ & 0.1861 & 7113.96 & 0.9987 & 0.878 & 96 \\
\hline NS 6830-22 & $\begin{array}{l}7112.61 \\
7114.32 \\
7114.40\end{array}$ & $\begin{array}{l}31.905 \\
52.043 \\
16.052\end{array}$ & 0.1268 & 7113.78 & 0.9988 & 0.680 & 69 \\
\hline Banias & $\begin{array}{l}7112.99 \\
7114.20\end{array}$ & $\begin{array}{l}11.861 \\
88.139\end{array}$ & 0.1748 & 7114.06 & 0.9996 & 0.887 & 97 \\
\hline \multicolumn{6}{|c|}{ Mn K-edge } & & \\
\hline BAS 4 & $\begin{array}{l}6538.84 \\
6539.75\end{array}$ & $\begin{array}{l}27.809 \\
72.191\end{array}$ & 0.0968 & 6539.50 & 0.9988 & & \\
\hline BAS 47 & $\begin{array}{l}6538.96 \\
6539.98\end{array}$ & $\begin{array}{l}28.703 \\
71.297\end{array}$ & 0.0897 & 6539.68 & 0.9991 & & \\
\hline BAS 56 & $\begin{array}{l}6538.84 \\
6539.81\end{array}$ & $\begin{array}{l}24.787 \\
75.213\end{array}$ & 0.0947 & 6539.57 & 0.9989 & & \\
\hline BAS 63 & $\begin{array}{l}6538.95 \\
6539.88\end{array}$ & $\begin{array}{l}38.203 \\
61.796\end{array}$ & 0.0902 & 6539.52 & 0.9985 & & \\
\hline BAS 71 & $\begin{array}{l}6538.90 \\
6539.87\end{array}$ & $\begin{array}{l}27.291 \\
72.709\end{array}$ & 0.0954 & 6539.29 & 0.9994 & & \\
\hline Carthage & 6539.60 & 100 & 0.1127 & 6539.60 & 0.9990 & & \\
\hline NS 6830-27 & 6539.64 & 100 & 0.1182 & 6539.64 & 0.9987 & & \\
\hline NS 6830-22 & $\begin{array}{l}6538.86 \\
6539.82\end{array}$ & $\begin{array}{l}25.662 \\
74.337\end{array}$ & 0.0904 & 6539.58 & 0.9990 & & \\
\hline Banias & 6539.64 & 100 & 0.1179 & 6539.64 & 0.9992 & & \\
\hline
\end{tabular}




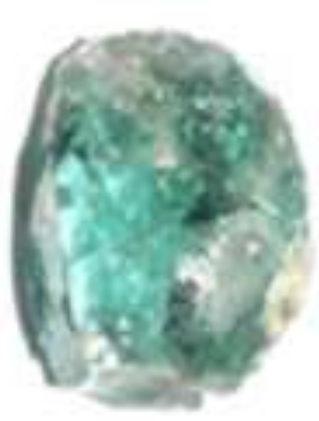

BET EL 2

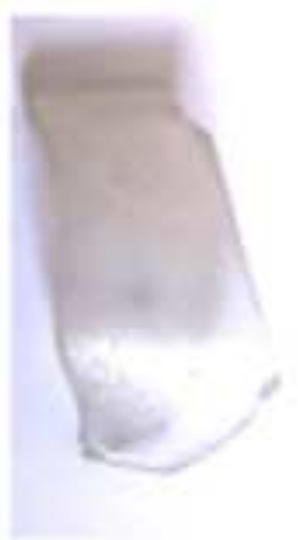

BAS 47

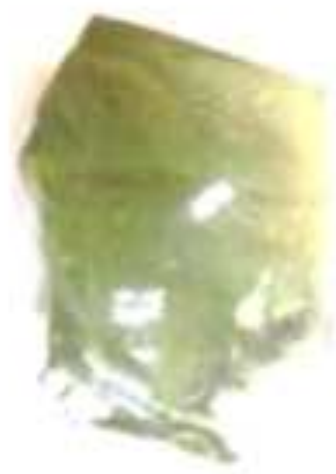

BET EL 3

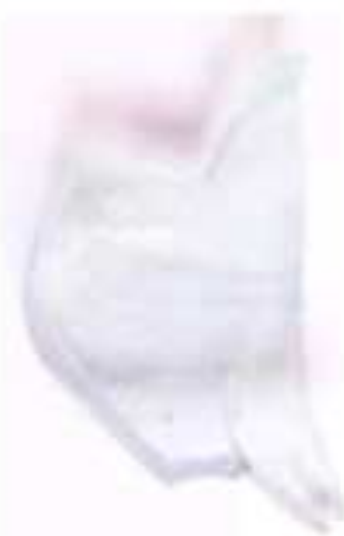

BAS 56

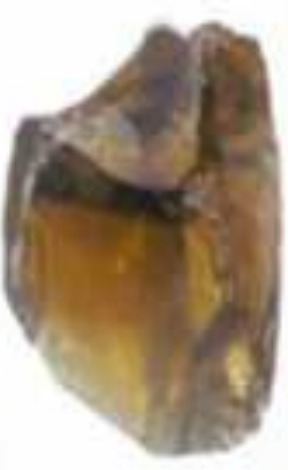

BET EL 4

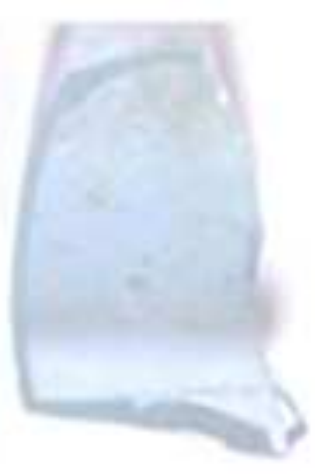

BAS 63

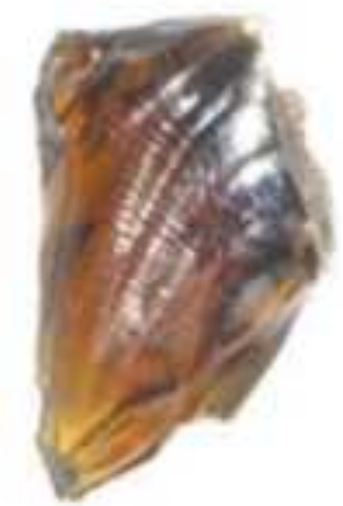

BET EL 239

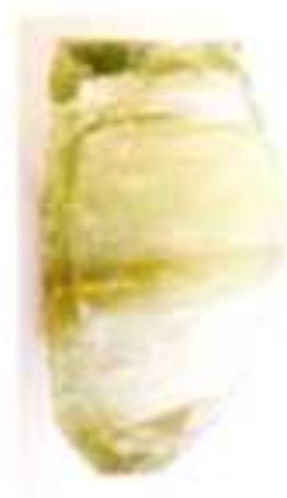

BAS 71 
Figure $2 a$

Click here to download high resolution image

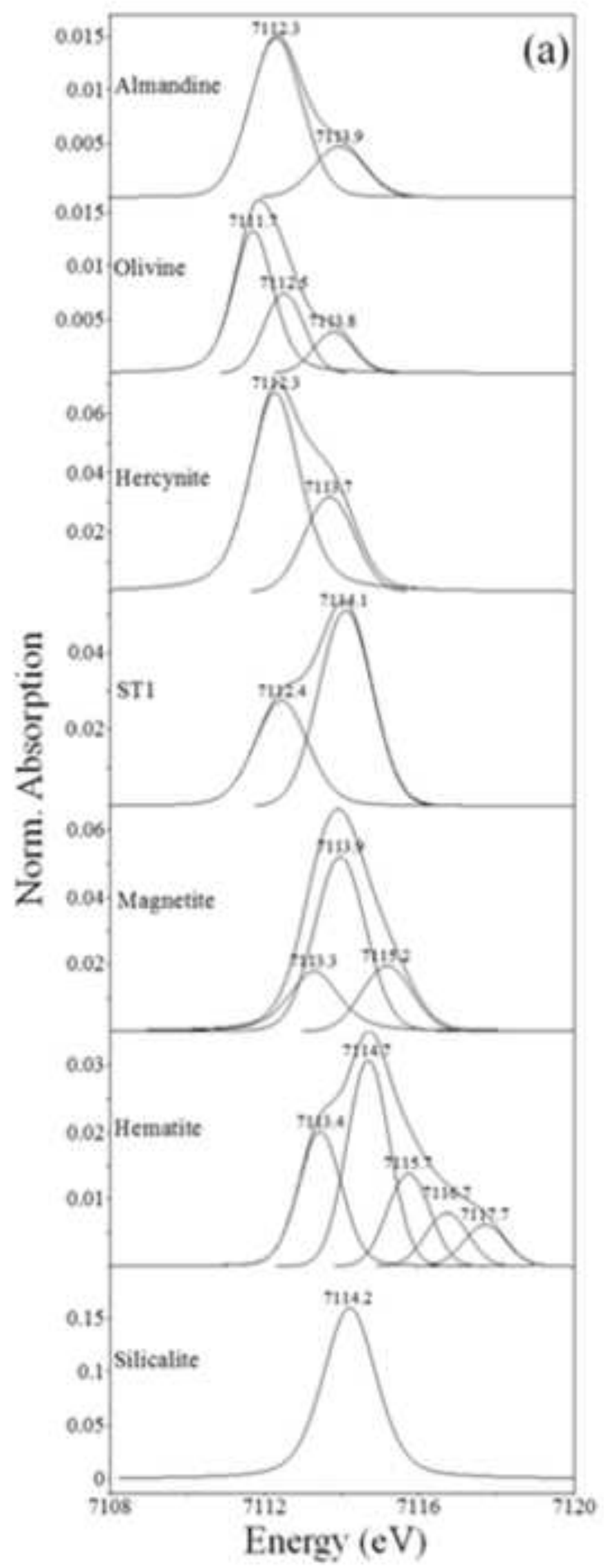

Click here to down load high resolution image 
BAS 4

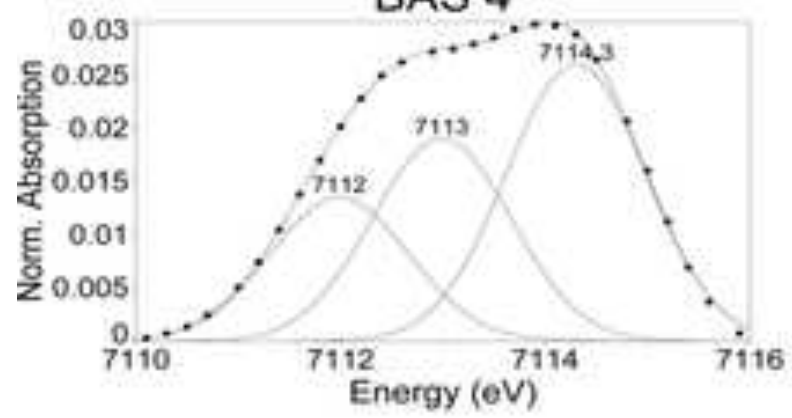

BAS 46

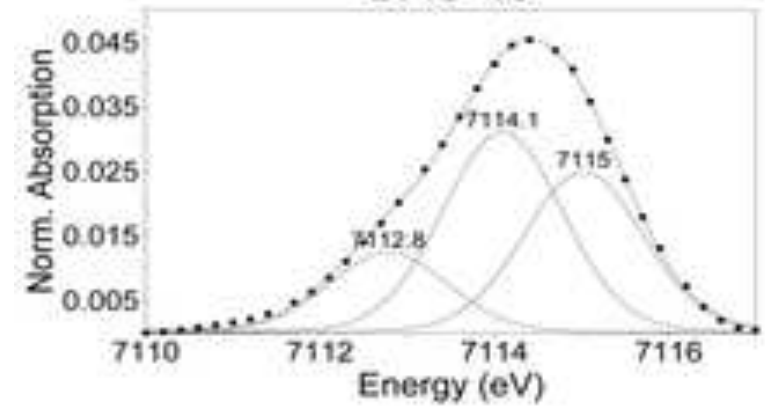

BAS 47

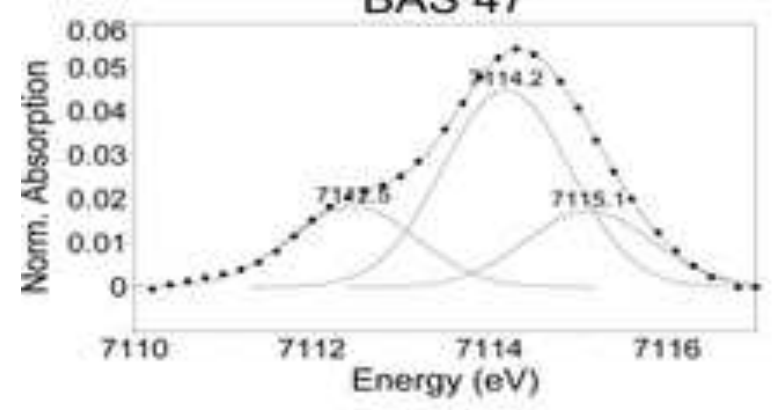

BAS 71

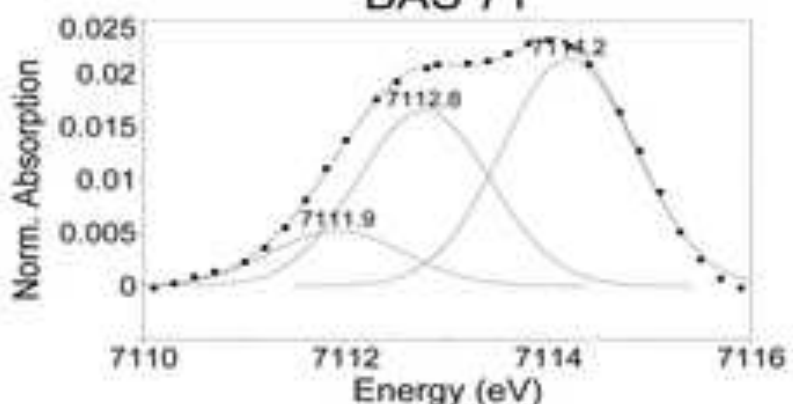

BET EL 2

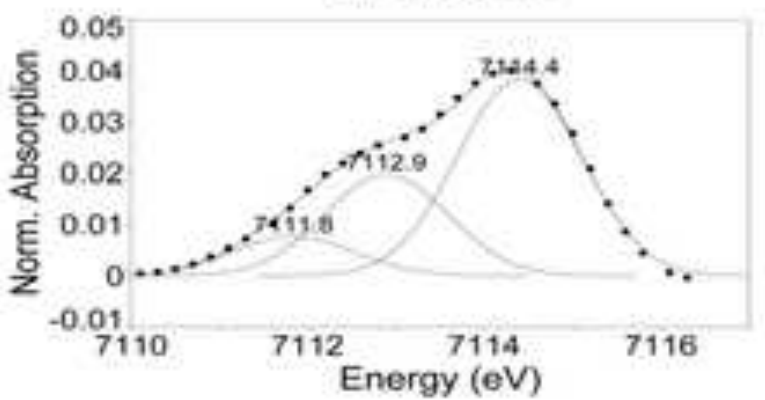

BET EL 3

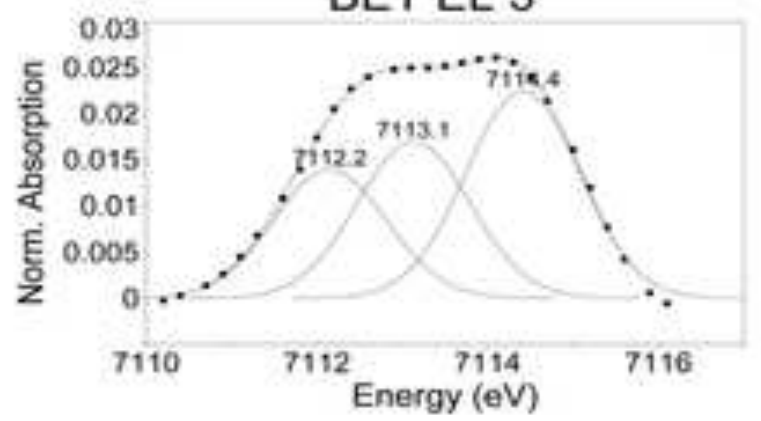

BET EL 4

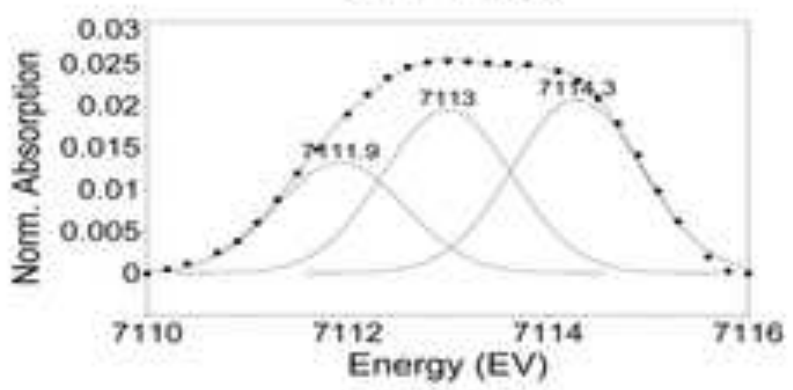

CARTHAGE

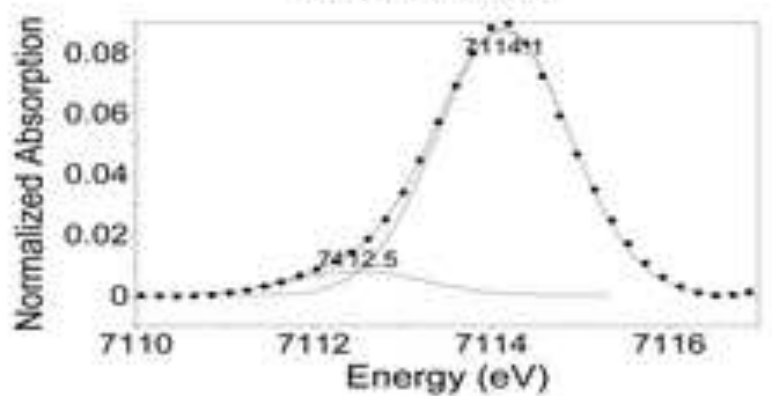

NS $6830-27$

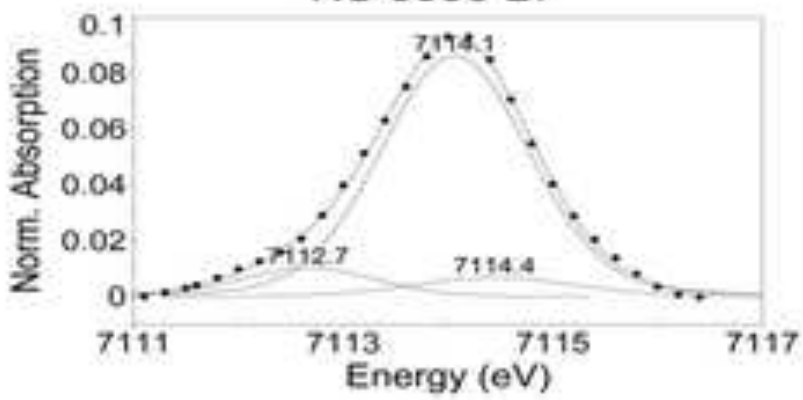


Figure $3 a$

Click here to download high resolution image

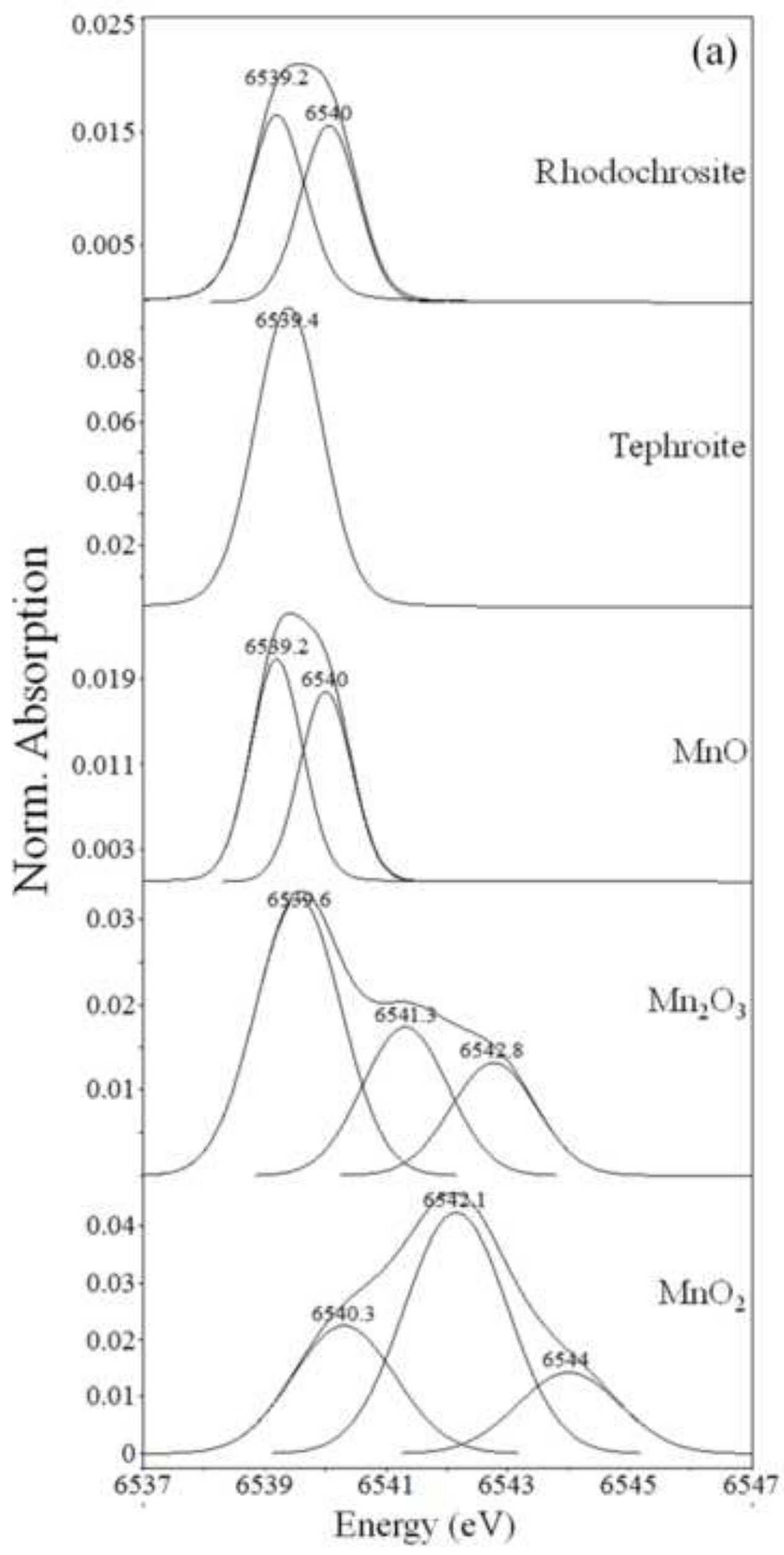



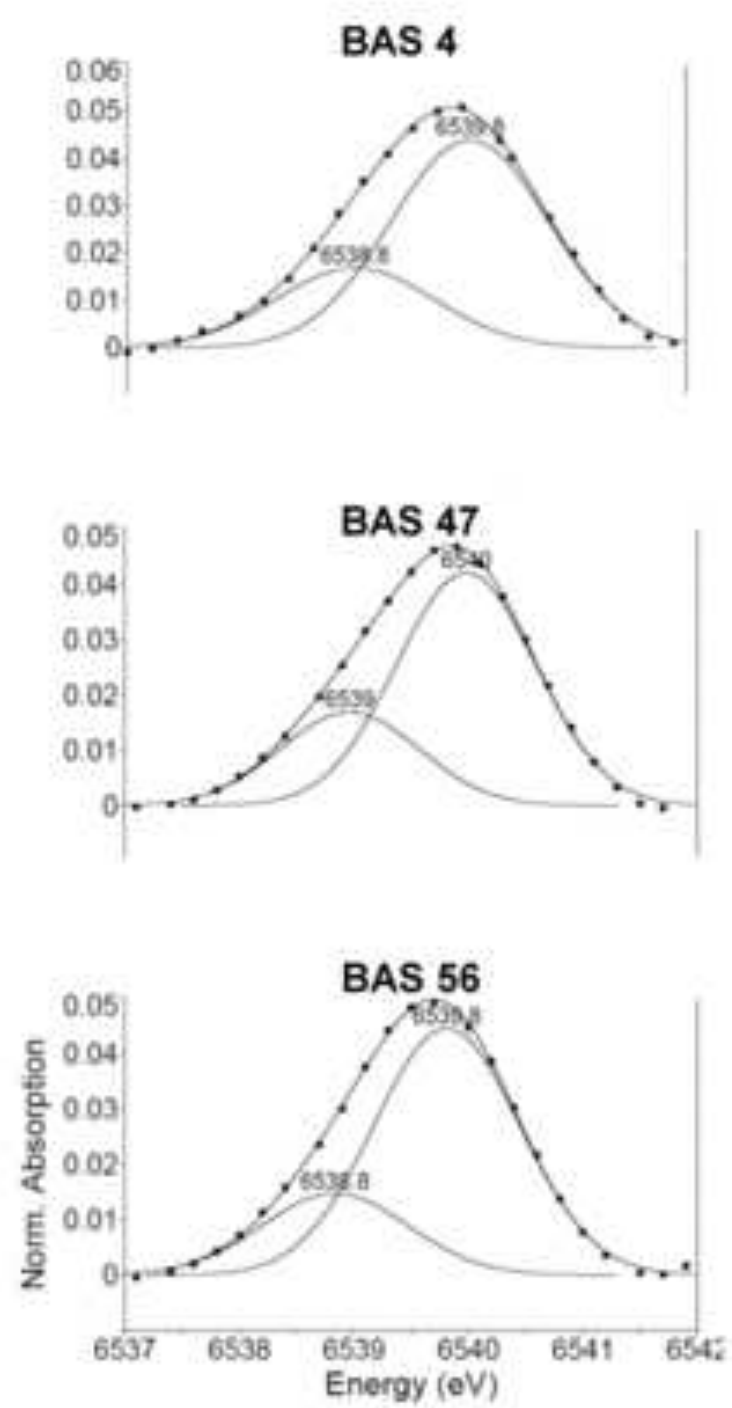
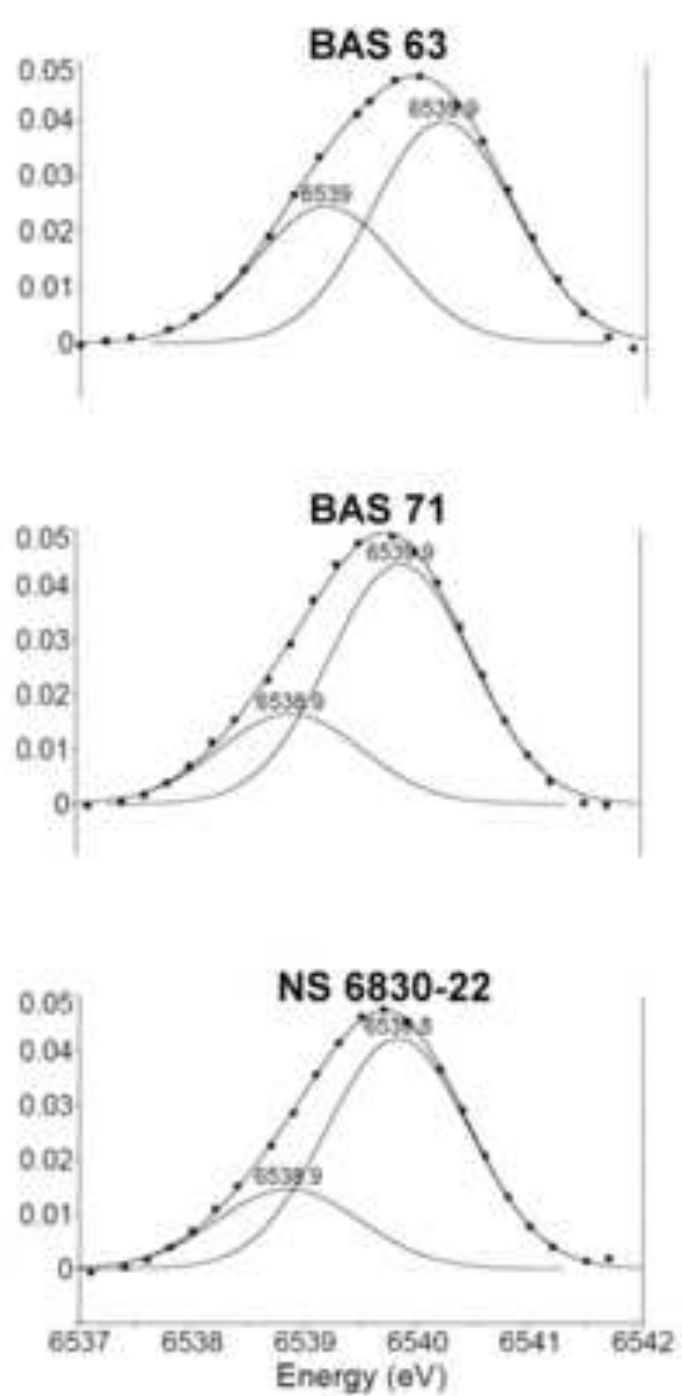
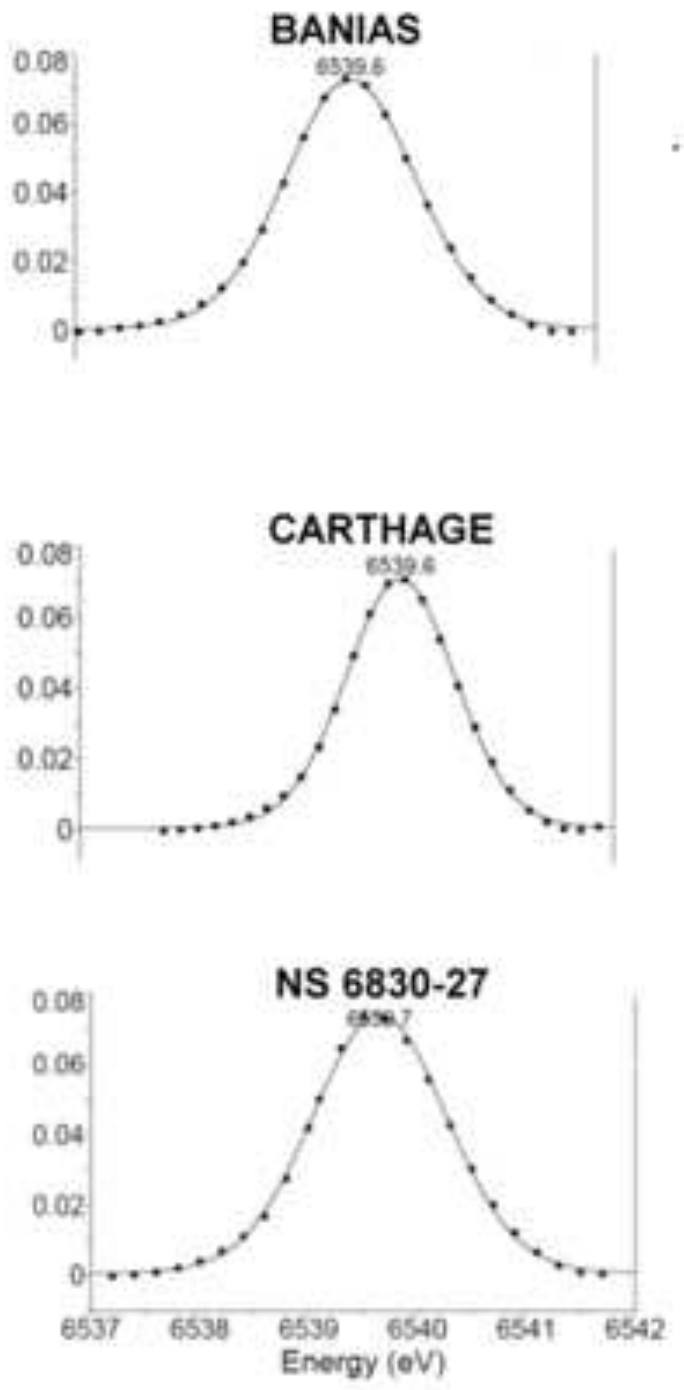


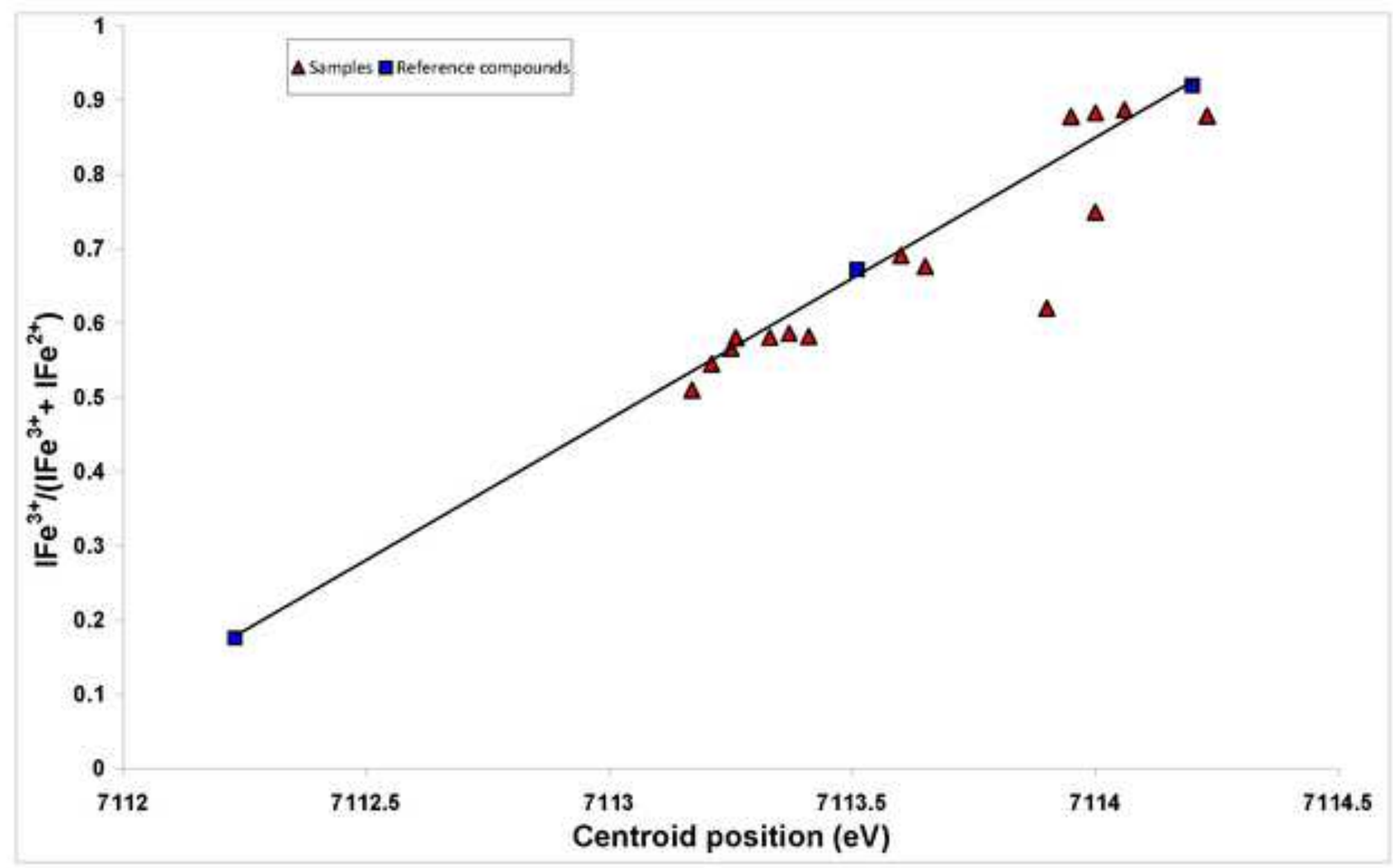

